\title{
Apoptosis induced by adenosine involves endoplasmic reticulum stress in EC109 cells
}

\author{
LING-FEI WU ${ }^{1}$, BI-LIU WEI ${ }^{1}$, YI-TIAN GUO ${ }^{1}$, YAN-QING YE ${ }^{1}$, GUO-PING LI $^{1}$, ZE-JIN PU ${ }^{1}$ and JIA-LIN FENG ${ }^{2}$ \\ Departments of ${ }^{1}$ Gastroenterology and ${ }^{2}$ Information, The Second Affiliated Hospital, \\ Shantou University Medical College, Shantou 515041, P.R. China
}

Received June 2, 2012; Accepted July 23, 2012

DOI: $10.3892 /$ ijmm.2012.1085

\begin{abstract}
Apoptosis plays a critical role in the development and homeostasis of multicellular organisms, and endoplasmic reticulum stress (ERS) is one of the intrinsic apoptosis pathways. Previous studies have shown that adenosine induces apoptosis in several cancer cell lines. However, the molecular mechanism remains poorly understood. In this study, we explored whether adenosine triggers apoptosis of EC109 esophageal carcinoma (EC) cells by ERS. The MTT assay was used to determine cell proliferation; cell cycle detection (FCM) and terminal deoxynucleotidyl transferase-mediated dUTP nick end labeling (TUNEL) assay were performed to determine cell apoptosis. The subcellular distribution and expression of the ERS-related proteins GRP78, cleaved caspase-3, cleaved caspase-4, CHOP and NF- $\kappa \mathrm{B}$ p65 were detected by western blot techniques. NF- $\kappa \mathrm{B}$ activation was measured by electrophoretic mobility shift assay (EMSA). The MTT assay demonstrated that adenosine inhibited EC109 cell proliferation in a dose- and time-dependent manner. FCM and TUNEL assay verified that adenosine caused an apoptotic peak in cell cycle arrest and a higher percentage of apoptotic cells. Western blot analysis confirmed that the expression of GRP78, cleaved caspase-4, $\mathrm{CHOP}, \mathrm{NF}-\kappa \mathrm{B}$ p 65 and cleaved caspase-3 were upregulated in a dose-dependent manner after adenosine treatment. EMSA revealed that adenosine activated $N F-\kappa B$ p 65 . This is the first demonstration that adenosine inhibits cell proliferation, increases GRP78 and NF- $\kappa$ B p65 expression and induces apoptosis by CHOP and caspase- 4 pathways. The ERS pathway is involved in adenosine-induced apoptosis in EC109 cells.
\end{abstract}

\section{Introduction}

Esophageal carcinoma (EC) ranks as the seventh and sixth in terms of cancer incidence and mortality in the world (1),

Correspondence to: Professor Ling-Fei Wu, Department of Gastroenterology, The Second Affiliated Hospital, Shantou University Medical College, Shantou 515041, P.R. China

E-mail: lingfeiwu@21cn.com

Key words: adenosine, apoptosis, endoplasmic reticulum stress, glucose-regulated protein 78, C/EBP homologous protein, EC109 cells and recent evidence shows that its incidence is gradually increasing. Moreover, nearly $50 \%$ of EC cases in the world occurred in China (2) and Shantou is a high-risk region of the disease. Prognosis of this disease is poor, with an overall 5-year survival rate of $<10 \%$. Even in resectable stages, the results of standard therapy modalities (surgery or radiotherapy) have been poor, with 5-year survival rates of approximately $20 \%$. Traditional approaches to cancer therapy involve surgery, radiation therapy and chemotherapy. More recent efforts target specific biochemical mechanisms, such as apoptotic pathways.

Adenosine, a metabolite of ATP, is abundantly present inside and outside cells, and exerts diverse biological actions in a wide range of cell types (3). However, high concentrations of nucleotides and their analogues can interfere with the synthesis of nucleic acids and exert cytotoxic activity by incorporating with and altering the DNA or RNA macromolecules, or by modifying the metabolism of physiologic nucleotides (4), which make them exciting candidates for anticancer therapy $(5,6)$. In our previous studies, adenosine induced human hepatoma HepG2 cell apoptosis (7). However, whether adenosine has anticancer effects on human EC is still unknown.

Apoptosis mediated by endoplasmic reticulum stress (ERS) plays a key role in many diseases, such as diabetes and Alzheimer's disease (8). The ER is the primary site for secretory protein synthesis and maturation, $\mathrm{Ca}^{2+}$ storage and lipid biosynthesis. Various stimuli can disturb ER homeostasis and result in the accumulation of unfolded and misfolded proteins and pathological consequences, namely ERS (9). Meanwhile, the accumulating unfolded proteins activate an adaptive signaling cascade known as unfolded protein response (UPR) (10). In response to ERS, ER chaperones such as $78 \mathrm{kDa}$ glucose-regulated protein (GRP78) are upregulated to stabilize protein folding. GRP78 belongs to the heat shock protein 70 (HSP70) family member and generally, it is highly expressed in various types of tumor tissues, resulting in the promotion of tumor cell survival, resistance to chemotherapy, higher incidence of malignancy and poorer prognosis (11). Notably, GRP78 is localized to the plasma membrane of tumor cells where it has receptor-like functions which are associated with increased cellular proliferation and survival (12). The early UPR enhances cell survival by UPR- and ER-associated protein degradation to ensure that the adverse 
effects of ERS are dealt with in a timely and efficient manner. However, prolonged activation of ERS can turn on a cell death pathway through activation of $\mathrm{C} / \mathrm{EBP}$ homologous protein (CHOP) (13), caspase-12 (14) and/or c-JUN NH2-terminal kinase (JNK) (15). In the present study, we investigated whether adenosine induces EC109 cell apoptosis and if so, the possible ERS-relative molecular mechanisms.

\section{Materials and methods}

Materials. The kit for terminal deoxynucleotidyl transferasemediated dUTP nick end labeling (TUNEL) was from Roche Applied Science (Indianapolis, IN, USA). 4',6-Diamidino2-phenylindol dihydrochloride (DAPI), propidium iodide (PI), phenylmethylsulfonylfluoride (PMSF), and protease inhibitor cocktail were from Sigma (St. Louis, MO, USA). Primary antibodies against anti- $\beta$-actin, caspase- 3 , cleaved caspase-3, caspase-4, cleaved caspase-4, NF- $\kappa$ B p65, CHOP and all secondary antibodies were purchased from Santa Cruz Biotechnology, Inc. (Santa Cruz, CA, USA). Nitrocellulose membrane was from Hybond-C (Amersham Life Science, UK), and an enhanced chemiluminescence detection reagent (ECL kit) was from Thermo Scientific (Rockford, IL, USA). The ${ }^{32} \mathrm{P}$-labeled $\gamma$-ATP $(3,000 \mathrm{Ci} / \mathrm{mmol})$ was from Furui Biotech Co. (Beijing, China). NF- $\kappa \mathrm{B}$ oligonucleotide probe (forward, 5'-AGT TGA GGG GAC TTT CCC AGG C-3' and reverse, 3'-TCA ACT CCC CTG AAA GGG TCC G-5'), adenosine, SDS and MTT were from Sangon (Shanghai, China); T4 Polynucleotide Kinase and poly(dI-dC)-poly(dI$\mathrm{dC}$ ) were from Promega Corporation (Madison, WI, USA). All other chemicals and reagents were of analytical grade.

Cell culture and treatment. EC109 cells were grown in DMEM supplemented with $10 \%$ fetal bovine serum, $1 \%$ penicillin-streptomycin (final concentration $100 \mathrm{U} / \mathrm{ml}$ and $100 \mu \mathrm{g} / \mathrm{ml}$ streptomycin), in a humidified atmosphere of $5 \% \mathrm{CO}_{2}$ and $95 \%$ air at $37^{\circ} \mathrm{C}$. Cells were detached by $0.25 \%$ trypsin $/ 0.02 \%$ EDTA. For the immunofluorescence assay and TUNEL assay, cells were cultured on coverslips in DMEM for $12 \mathrm{~h}$ before addition of adenosine.

Cell proliferation. EC109 cells were seeded at a density of $2 \times 10^{5} /$ well in a 96 -well plate with $200 \mu \mathrm{l}$ culture medium. After the cells were attached, the original medium was replaced with fresh medium containing different concentrations of adenosine $(0-4.0 \mathrm{mmol} / \mathrm{l})$ for $36 \mathrm{~h}$ or containing $2.0 \mathrm{mmol} / 1$ adenosine for 0 to $72 \mathrm{~h}$. The cells were then incubated at $37^{\circ} \mathrm{C}$ with $20 \mu 1 \mathrm{MTT}(500 \mu \mathrm{g} / \mathrm{ml})$ for another $4 \mathrm{~h}$ in a $5 \% \mathrm{CO}_{2}$ incubator. The medium was removed and $150 \mu \mathrm{l}$ DMSO was added to each well, followed by thermal agitation for $5 \mathrm{~min}$ protected from light. The optical density of each well was read at $490 \mathrm{~nm}$ using a microplate reader (Wellscan K3; KHB Labsystems, Finland). MTT is taken only into viable cells, and the MTT intensity corresponds to the number of viable cells. To assess cell viability, the percentage of the independent basal levels (MTT intensities of cells untreated with adenosine) was calculated.

Cell cycle analysis. After EC109 cells were treated with different concentrations of adenosine (0-4.0 mmol/l) for $36 \mathrm{~h}$, cells in the supernatant were collected by centrifugation and combined with adherent cells that had been trypsinized. Cells were then washed with $5 \mathrm{ml}$ PBS (pH 7.2) and fixed in $70 \%$ ethanol at $4^{\circ} \mathrm{C}$ overnight. Cells were washed twice with PBS to remove the ethanol and passed through a $0.44-\mathrm{mm}$ filter to remove aggregates. The cells were incubated in PBS containing RNase A $(2.0 \mu \mathrm{g} / \mathrm{ml})$ for $1 \mathrm{~h}$ at $37^{\circ} \mathrm{C}$, followed by staining with PI $(5.0 \mu \mathrm{g} / \mathrm{ml})$ for $20 \mathrm{~min}$ protected from light on ice. Cells were collected on a nylon mesh filter (pore size, $40 \mu \mathrm{m}$ ) and cell cycle phases including the sub- $\mathrm{G}_{1}$ phase (apoptotic cells) were assayed with a flow cytometer (FACSCalibur; Becton-Dickinson, USA) at an excitation of $488 \mathrm{~nm}$ and an emission of $585 \mathrm{~nm}$ and analyzed using Lysis II software. A total of $1 \times 10^{4}$ cells were counted for each sample. Data were obtained from experiments performed in triplicate.

TUNEL assay. EC109 cells were incubated for $36 \mathrm{~h}$ with different concentrations of adenosine (0-4.0 mmol/1), cells were washed with ice-cold PBS and fixed with $10 \%$ paraformaldehyde. Cells were subsequently washed 3 times with PBS and permeabilized by $0.2 \%$ Triton X-100 in PBS for $5 \mathrm{~min}$ at room temperature. After washing twice, cells were equilibrated for $10 \mathrm{~min}$ in equilibration buffer [200 $\mathrm{mmol} / 1$ potassium cacodylate, $25 \mathrm{mmol} / 1$ Tris-HC1, $\mathrm{pH} 6.6,0.2 \mathrm{mmol} / 1$ dithiothreitol (DTT), $0.25 \mathrm{mg} / \mathrm{ml} \mathrm{BSA,} 2.5 \mathrm{mmol} / 1$ cobalt chloride] and incubated in TdT reaction mixture (equilibration buffer $98 \mu \mathrm{l}$, biotinylated nucleotide mix $1 \mu \mathrm{l}$ and TdT enzyme $1 \mu \mathrm{l}$; total volume $100 \mu \mathrm{l}$ ) at $37^{\circ} \mathrm{C}$ for $60 \mathrm{~min}$ in humidified chambers. After immersing the slides in $2 \mathrm{X} \mathrm{SSC}(\mathrm{NaCl}$, sodium citrate) for $15 \mathrm{~min}$ at room temperature and washing the slides twice in PBS, endogenous peroxidases were blocked by immersing the slides in $0.3 \%$ hydrogen peroxide for $5 \mathrm{~min}$ at room temperature. Slides were then incubated with horseradish-peroxidase-labeled streptavidin (HRP) solution for $30 \mathrm{~min}$ and washed twice with PBS. Finally, slides were incubated with diaminobenzidine (DAB) components for $10 \mathrm{~min}$ and examined under a light microscope. All experiments were performed 3 times. TUNEL-positive (brown staining) cells were defined as apoptotic cells and 6 randomly selected microscopic fields in each group were used to calculate the percent of TUNEL-positive cells.

Western blot analysis. After adenosine treatment, EC109 cells were washed with ice-cold PBS, harvested and lysed on ice in RIPA buffer $[0.25 \%(\mathrm{w} / \mathrm{v})$ sodium deoxycholate, $0.1 \%(\mathrm{v} / \mathrm{v})$ Triton X-100, $150 \mathrm{mM} \mathrm{NaCl}, 0.5 \%$ Nonidet P-40, $50 \mathrm{mM}$ Tris-HCl ( $\mathrm{pH} 7.4)]$ with the addition of protease inhibitor cocktail (Sigma). Cell lysates were centrifuged at 12,000 rpm at $4^{\circ} \mathrm{C}$ for $10 \mathrm{~min}$. The supernatant $\left[20 \mu \mathrm{g}\right.$ including the sub- $\mathrm{G}_{1}$ phase (protein/well)] was boiled for $5 \mathrm{~min}$ and subjected to $12 \%$ sodium dodecylsulfate polyacrylamide gel electrophoresis (SDS-PAGE) and transferred to a nitrocellulose membrane. Membranes were blocked with 5\% non-fat milk for $30 \mathrm{~min}$ at room temperature, followed by incubation with a primary antibody against $\beta$-actin (1:1,000), GRP78 (1:800), caspase-3 (1:800), cleaved caspase-3 (1:800), caspase-4 (1:400), cleaved caspase-4 (1:800), CHOP (1:500) or NF- $\kappa \mathrm{B}$ p65 (1:500) at $4^{\circ} \mathrm{C}$ overnight and with a secondary antibody (HRP-conjugated anti-goat or anti-rabbit $\mathrm{IgG}$ ) for $1 \mathrm{~h}$. Protein 
expression was analyzed by NIH image software and normalized to that of $\beta$-actin.

Electrophoretic mobility shift assay. The EC109 cells were treated with $2.0 \mathrm{mmol} / \mathrm{l}$ adenosine for $36 \mathrm{~h}$. The cells were rinsed with ice-cold PBS and centrifuged. The cell pellets were resuspended with buffer A [10 mmol/1 HEPES ( $\mathrm{pH} 7.9$ ), $1.5 \mathrm{mmol} / 1 \mathrm{MgCl}_{2}, 15 \mathrm{mmol} / 1 \mathrm{KCl}, 1 \mathrm{mmol} / 1 \mathrm{DTT}, 0.5 \mathrm{mmol} / 1$ PMSF, $0.1 \mathrm{mmol} / 1$ EDTA, $0.1 \mathrm{mM}$ EGTA, leupeptin, aprotinin and pepstatin $(2 \mu \mathrm{g} / \mathrm{ml}$ each)] for $10 \mathrm{~min}$ on ice. After centrifugation, the pellets were resuspended with buffer $\mathrm{A}$ containing $0.5 \%(\mathrm{v} / \mathrm{v})$ Nonidet P-40 and further incubated for $10 \mathrm{~min}$ on ice. The cell suspension was then centrifuged at $4^{\circ} \mathrm{C}$ for $20 \mathrm{~min}$ at $3,000 \mathrm{rpm}$. The nuclear pellets were resuspended with buffer $\mathrm{B}$ [20 mmol/1 HEPES ( $\mathrm{pH} 7.9$ ), $420 \mathrm{mmol} / 1 \mathrm{NaCl}, 1.5 \mathrm{mmol} / 1 \mathrm{MgCl}_{2}, 0.2 \mathrm{mmol} / 1$ EDTA, $0.5 \mathrm{mmol} / 1 \mathrm{PMSF}, 0.5 \mathrm{mmol} / 1 \mathrm{DTT}, 25 \%$ (v/v) glycerol, leupeptin, aprotinin and pepstatin $(2 \mu \mathrm{g} / \mathrm{ml}$ each)]. The resuspended nuclei were then extracted by rocking at $40^{\circ} \mathrm{C}$ for $1 \mathrm{~h}$, then centrifuging for $20 \mathrm{~min}$ at $10,000 \mathrm{rpm}$. The supernatant (nuclear proteins) was collected and protein concentration was determined using a Bradford protein assay. The EMSA method used was similar to that described previously (16), with slight modifications. A double-stranded NF- $\kappa$ B oligonucleotide probe (forward, 5'-AGT TGA GGG GAC TTT CCC AGG C-3' and reverse, 3'-TCA ACT CCC CTG AAA GGG TCC G-5') was end-labeled with $\left[\gamma^{-}{ }^{32} \mathrm{P}\right] \mathrm{ATP}$. The labeling reaction system contained T4 Polynucleotide Kinase buffer and T4 Polynucleotide Kinase $(10 \mu / \mu \mathrm{l})$, nuclease-free water, $\left[\gamma^{32} \mathrm{P}\right]$ ATP $(3,000 \mathrm{Ci} / \mathrm{mmol}$ at $10 \mathrm{mCi} / \mu \mathrm{l})$ and unlabeled probe $(10 \mathrm{pmol} / \mu \mathrm{l})$. Ten milligrams of nuclear extraction was incubated for $10 \mathrm{~min}$ at room temperature with binding buffer [10 mmol/1 HEPES (pH 7.9), $50 \mathrm{mmol} / 1 \mathrm{KCl}, 0.2 \mathrm{mmol} / 1$ EDTA, $2.5 \mathrm{mmol} / 1 \mathrm{DTT}, 0.05 \%$ (v/v) Nonidet P-40, 10\% (v/v) glycerol and $1 \mu \mathrm{g} / \mu \mathrm{l}$ poly (dI-dC)-poly(dI-dC)]. Labeled $\mathrm{NF}-\kappa \mathrm{B}$ oligo was then added and the reaction was allowed to proceed for a further $20 \mathrm{~min}$ at room temperature. In competition experiments, a 100-fold molar excess of the cold unlabeled oligonucleotide was added to the nuclear extracts for $30 \mathrm{~min}$ before addition of a radiolabeled probe. The specific antibody against NF- $\kappa \mathrm{B}$ p65 protein (final concentration $0.1 \mu \mathrm{g} / \mu \mathrm{l}$ ) was pre-incubated with nuclear extracts in binding buffer for $30 \mathrm{~min}$ at room temperature before addition of the radiolabeled probe. Samples were then separated on $6 \%$ nondenaturing polyacrylamide gel electrophoresis with $0.5 \mathrm{X}$ Tris borate EDTA buffer at $4^{\circ} \mathrm{C}$. Dried gel was subjected to autoradiography at $-80^{\circ} \mathrm{C}$.

Statistical analysis. Data are expressed as means \pm SEM of at least 3 independent experiments. Results were analyzed with the unpaired Student's t-test or one-way ANOVA for different groups in SPSS 16.0. A $\mathrm{P}<0.05$ was considered to indicate a statistically significant result.

\section{Results}

Adenosine inhibits cell proliferation. EC109 cells were exposed to $2 \mathrm{mmol} / \mathrm{l}$ adenosine for different times from 24 to $72 \mathrm{~h}$ and cell proliferation was evaluated by MTT assay. The cell relative viabilities were decreased to $57.4,55.4,44.3$
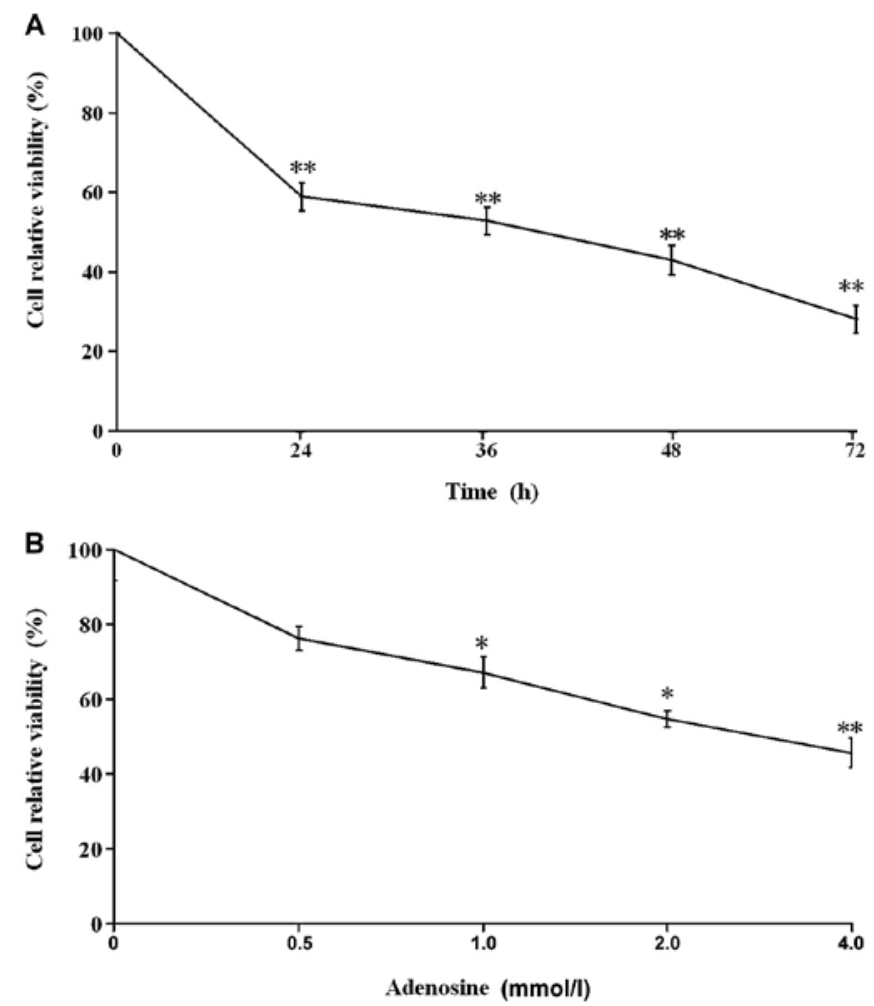

Figure 1. Time- and dose-dependent cytotoxic effects of adenosine on EC109 cells. (A) Cells were incubated with $2.0 \mathrm{mmol} / 1$ adenosine for different durations and the cell relative viabilities were significantly decreased, compared to the control group $(0 \mathrm{~h})$. (B) Cells were incubated with adenosine at different concentrations for $36 \mathrm{~h}$ and the cell numbers were significantly decreased, compared to the control group (absence of adenosine). Cell numbers were determined by MTT method. Data are presented as the means $\pm \mathrm{SD}$. Independent experiments were repeated 3 times. ${ }^{*} \mathrm{P}<0.05$, ${ }^{* *} \mathrm{P}<0.01$ vs. control group.

and $28.15 \%$, respectively, compared to the control group $(0 \mathrm{~h})$, showing that adenosine inhibited cell proliferation in a time-dependent manner $(\mathrm{P}<0.01)$ (Fig. 1A). EC109 cells were exposed to different concentrations of adenosine, 0.5, 1.0, 2.0 and $4.0 \mathrm{mmol} / 1$, for $36 \mathrm{~h}$, and the cell numbers were decreased to $88.2,67.1,54.7$ and $45.6 \%$, respectively, compared to cell numbers in the absence of the adenosine group, revealing adenosine inhibited cell proliferation in a dose-dependent manner $(\mathrm{P}<0.05$ and $\mathrm{P}<0.01)$ (Fig. 1B).

Adenosine induces apoptosis. To explore whether EC109 cell proliferation inhibition caused by adenosine was a result of necrosis or apoptosis, two separate methods were used for these experiments. In one case, we assessed and quantified the presence of apoptotic cells by performing cell cycle assay. After EC109 cells were exposed to various concentrations of adenosine for $36 \mathrm{~h}$, with adenosine concentration increasing, sub- $\mathrm{G}_{1}$ cell accumulation (hallmark of apoptosis) obviously appeared. The proportion of apoptotic cells in 0.5, 1.0, 2.0 and $4.0 \mathrm{mmol} / 1$ adenosine-treated groups was 6.2-, 12.2-, 17.5- and 21.1-fold higher, respectively than that observed in the control group (Fig. 2).

A more specific method for identifying apoptosis was used in a second set of experiments. DNA fragmentation, associated with apoptosis, generates many small nucleosomal-sized DNA fragments, which can be detected by the 

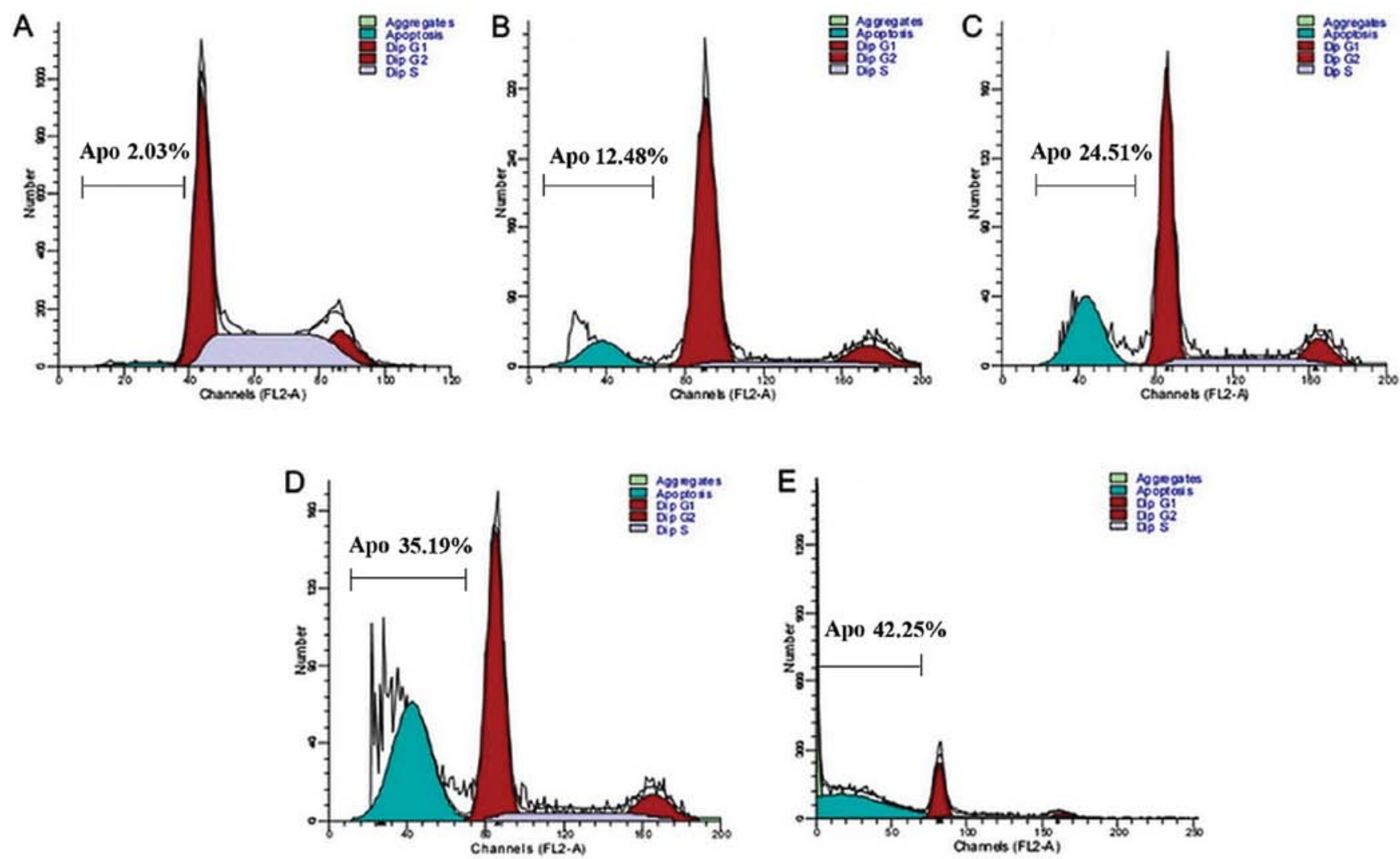

Figure 2. Effects of adenosine on EC109 cell cycles. EC109 cells were treated with various concentrations of adenosine $(0,0.5,1.0,2.0$ and $4.0 \mathrm{mmol} / \mathrm{l})$ for $36 \mathrm{~h}$. Cell cycle phases were determined by propidium iodine staining, followed by flow cytometric analysis. The percentages of apoptotic cells in the sub- $\mathrm{G}_{1}$ phase (blue peak) were detected and analyzed by the WinMDI 2.9 software.
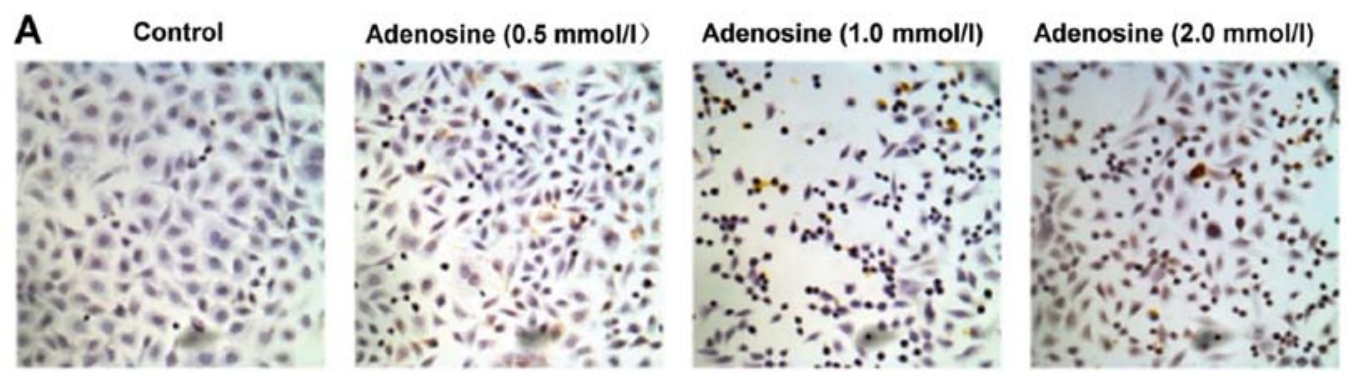

\section{B}
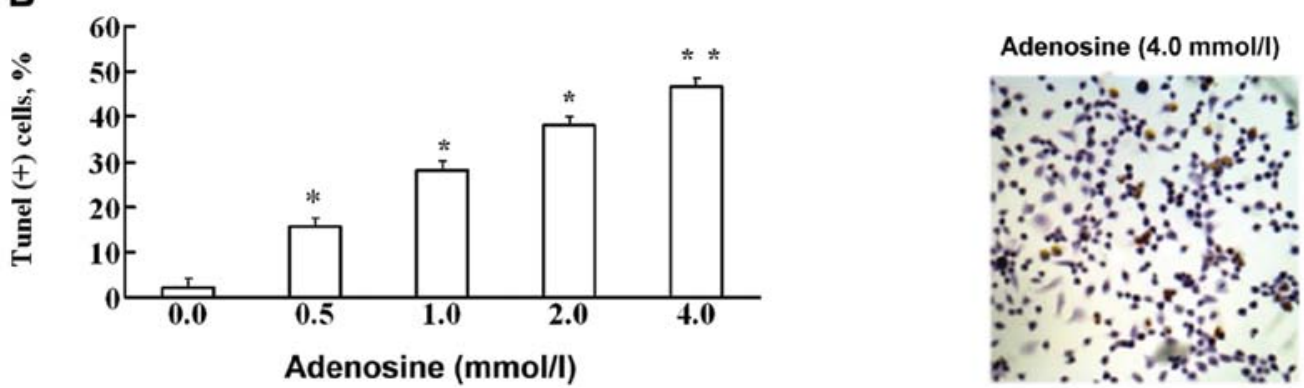

Figure 3. Effects of adenosine on EC109 cell apoptosis by TUNEL analysis. (A) EC109 cells were treated with various concentrations (0-4.0 mmol/1) of adenosine for $36 \mathrm{~h}$. Apoptotic cells were identified by light microscopy as cells having dark brown nuclei. (B) Apoptotic cells were quantified by counting a minimum of 6 fields of 100 cells/field (magnification, $\mathrm{x} 400$ ), ${ }^{*} \mathrm{P}<0.05,{ }^{* *} \mathrm{P}<0.01$ vs. control (absence of adenosine).

TUNEL method. These new DNA fragments increase the number of 3'-OH ends. Incorporating digoxigenin-conjugated nucleotides, via end extension, into these small nucleosomal fragments identifies cells with significant DNA fragmenta- tion. Adenosine treatment caused the appearance of cells with apoptotic (dark brown colored) nuclei (TUNEL-positive cells) (Fig. 3A). Adenosine increased the percentage of TUNEL-positive cells in a dose-dependent manner, as 

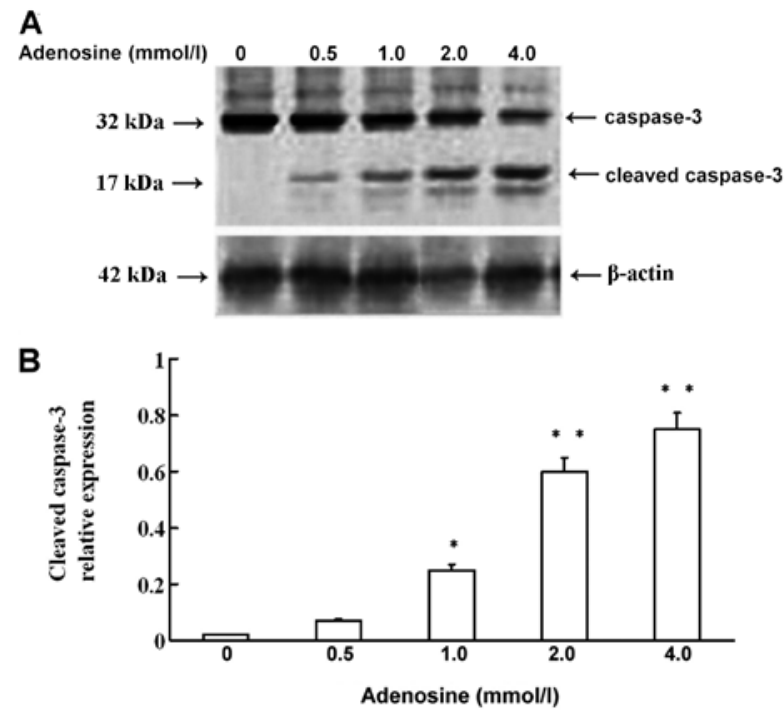

Figure 4. Effects of adenosine on cleaved caspase- 3 by western blot analysis. (A) EC109 cells were exposed to different concentrations of adenosine (0.5$4.0 \mathrm{mmol} / \mathrm{l})$ for $36 \mathrm{~h}$. Cell lysates were subjected to western blot analysis with a specific antibody against caspase- 3 or cleaved caspase-3. Blots shown are representative of $n=3$. (B) Ratio of cleaved caspase- 3 to $\beta$-actin. ${ }^{*} \mathrm{P}<0.05$, ${ }^{* *} \mathrm{P}<0.01$ vs. control (absence of adenosine).

compared with control cells (Fig. 3B) $(\mathrm{P}<0.05)$. The apoptotic cell percentage identified by the TUNEL method was in agreement with the apoptotic peak of the cell cycle assay. Adenosine also significantly increased cleaved caspase-3 expression in a dose-dependent, compared to the control group (Fig. 4) $(\mathrm{P}<0.05$ and $\mathrm{P}<0.01)$ and expression of procaspase-3 decreased, which showed that caspase-3 was activated and apoptosis occurred in the EC109 cells.

Adenosine upregulates ERS-related proteins. To assess whether ERS is activated after adenosine treatment, western blot analysis was used to analyze relative protein expression. The results showed that UPR chaperone GRP78 was significantly upregulated in the $1.0-4.0 \mathrm{mmol} / \mathrm{l}$ adenosine treatment groups, as compared with the control group (Fig. 5) (all $\mathrm{P}<0.05$ ), respectively. Caspase- 4 and CHOP are two key molecules in the three branches of ERS-associated apoptosis. Both cleaved caspase- 4 and CHOP were significantly increased in a concentration-dependent manner, compared to that of the control group (Fig. 5) $(\mathrm{P}<0.05$ and $\mathrm{P}<0.01)$; whereas the procaspase- 4 was decreased, indicating the increased processing of procaspase- 4 to active caspase- 4 after adenosine treatment. These results suggested that adenosine activated caspase- 4 and CHOP pathways by GRP78.

Adenosine induces $N F-\kappa B$ activation and expression. We performed EMSA on nuclear extracts from EC109 cells using a $\kappa B$ sequence from $\kappa$ light chain enhancer in order to observe the effect of different concentrations of adenosine on NF- $\mathrm{KB}$ p65 induction. As shown in Fig. 6A, adenosine stimulated DNA binding of NF- $\mathrm{KB}$ after $36 \mathrm{~h}$ of incubation at concentrations from 0.5 to $4.0 \mathrm{mmol} / \mathrm{l}$. The effects increased with the adenosine dosage; $4.0 \mathrm{mmol} / \mathrm{l}$ adenosine appeared to more strongly induce NF- $\mathrm{KB}$ activation (Fig. 6B) $(\mathrm{P}<0.01)$. Western blot analysis also revealed that NF- $\mathrm{\kappa B}$ significantly increased

\section{A}
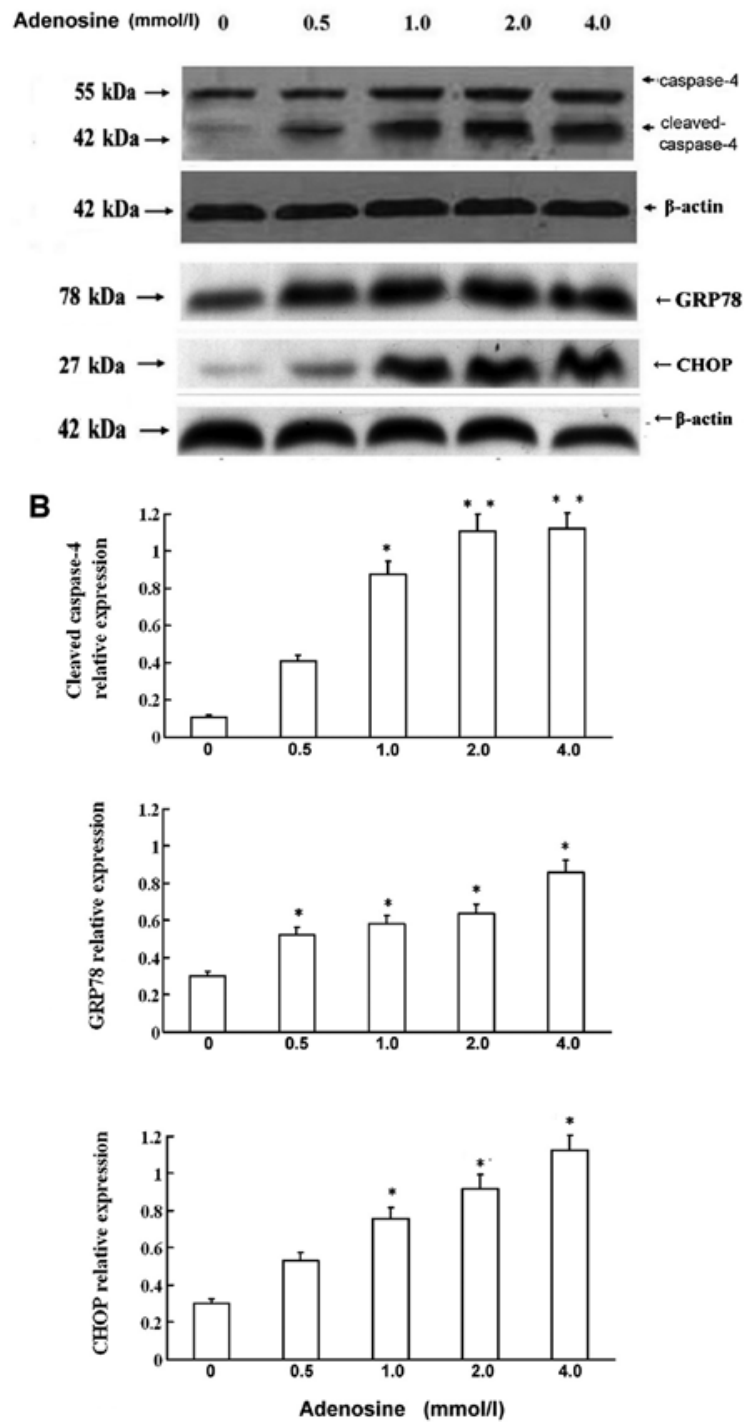

Figure 5. (A) Expression of ER stress marker-related proteins after adenosine exposure. EC109 cells were exposed to different concentrations of adenosine $(0.5-4.0 \mathrm{mmol} / \mathrm{l})$ for $36 \mathrm{~h}$. Cell lysates were subjected to western blot analysis with specific antibodies against GRP78, caspase-4, cleaved caspase-4, or CHOP. Blots shown are representative of $n=3$. (B) Band intensity analysis of ER stress marker-related protein expression. Band intensity analysis was performed with Quantity one software. The values represent the means \pm SD of 3 independent experiments. ${ }^{*} \mathrm{P}<0.05,{ }^{* *} \mathrm{P}<0.05$ vs. the control group.

in a dose-dependent manner, compared to the control group (Fig. $6 \mathrm{C}$ and $\mathrm{D})(\mathrm{P}<0.05$ and $\mathrm{P}<0.01)$.

\section{Discussion}

Adenosine belongs to the cytotoxic nucleotide analogue class of drugs. In physiological conditions, the average concentration of nucleotides in plasma and other extracellular fluids is generally in the range of 0.4-6 $\mu \mathrm{mol} / 1$. However, high concentrations of nucleotides and their analogues can interfere with the synthesis of nucleic acids and exert cytotoxic activity by incorporating with and altering the DNA or RNA macromolecules, or by modifying the metabolism of physiologic nucleotides (4), which make it an exciting candidate for anticancer therapy (17). 
A

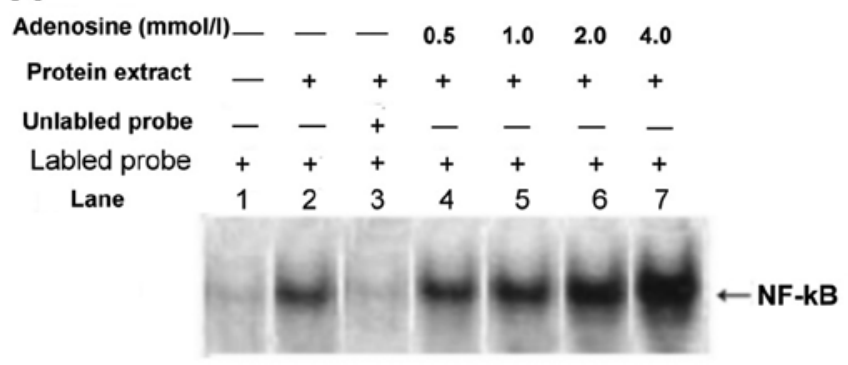

C

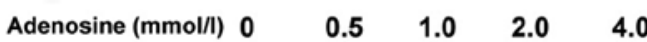

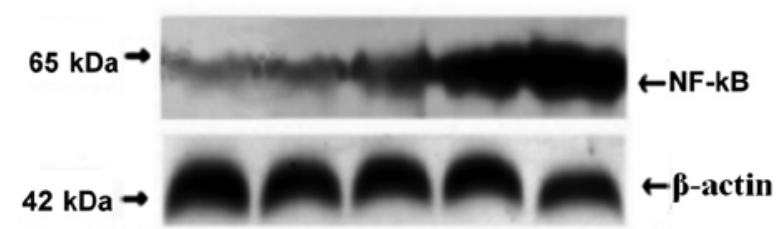

B

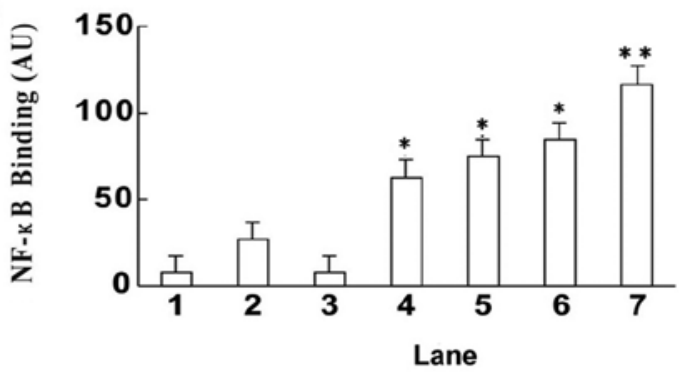

D

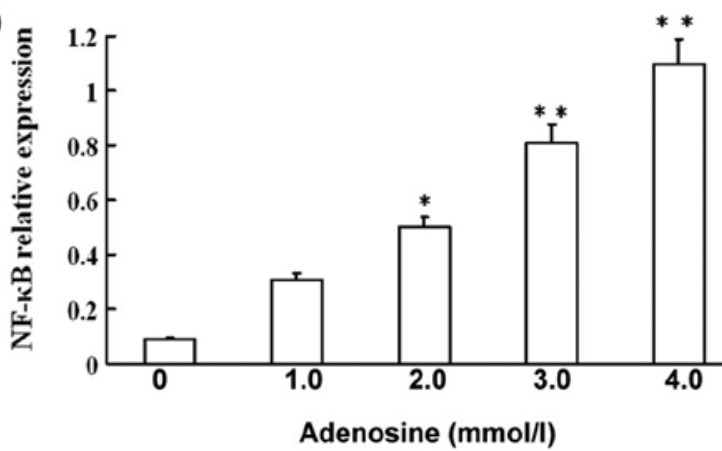

Figure 6. Effects of adenosine on NF- $\mathrm{B}$ p65 DNA binding and protein expression. (A) EC109 cells ( $2 \times 10^{6}$ cells) were incubated in culture medium alone (control, lane 2) or in the presence of different concentrations of adenosine (0.5-4.0 mmol/1, lanes 4-7) for 36 h. Nuclear extracts were subjected to EMSA analysis, as described in experimental procedures. The negative control contained the labeled probe and no protein in the binding reactions (lane 1). To demonstrate specificity of induced bands, binding was carried out in the presence of a molar excess (x100) of unlabeled probe containing NF- $\kappa \mathrm{B}$ consensus sequence (lane 3). Specific DNA-NF- $\kappa \mathrm{B}$ complex and free probes are indicated by the arrows. (B) Results of the densitometric analysis for the specific NF- $\mathrm{B}$ binding. Bands shown are representative of $n=3$. ( ${ }^{*} \mathrm{P}<0.05,{ }^{* *} \mathrm{P}<0.01$ vs. the control group-lane 2). (C) EC109 cells were exposed to different concentrations of adenosine for $36 \mathrm{~h}$. Cell lysates were subjected to western blot analysis using antibodies against NF- $\mathrm{B}$ p65 and $\beta$-actin. Blots shown are representative of $\mathrm{n}=3$. (D) Ratio of $\mathrm{NF}-\kappa \mathrm{B}$ to $\beta$-actin. ${ }^{*} \mathrm{P}<0.05,{ }^{* *} \mathrm{P}<0.01$ vs. control (absence of adenosine).

Since Rapaport and Fontaine (18) reported that extracellular adenine nucleotides had anticancer activity, adenosine and its analogues (8-Cl-adenosine) have been widely studied in various tumor cell lines, including human thyroid cancer lines (17), colonic cancer Caco-2 (19), breast cancer (20), hepatoma HepG2 (7) and multiple myeloma (21). In this study, EC109 cells were exposed to $2.0 \mathrm{mmol} / 1$ adenosine for different times from 24 to $72 \mathrm{~h}$ or exposed to different concentrations of adenosine for $36 \mathrm{~h}$. The results showed that adenosine significantly inhibited cell proliferation in a time-dependent and a dose-dependent manner (Fig. 1) and FCM and TUNEL methods verified that the extensive cell death was apoptosis (Figs. 2 and 3). The present experiment indicates that adenosine also has cytotoxic effects on EC109 cells.

In many conditions, the transcription of GRP78 is upregulated as part of a general cellular defense mechanism (UPR) (22-24). To assess whether UPR and ERS are activated after adenosine treatment, western blot analysis was used to analyze relative protein expression. The results showed that UPR chaperone GRP78 was significantly upregulated after adenosine treatment in a dose-dependent manner (Fig. 5), which was in agreement with other studies that chemotherapy drugs can induce GRP78 upregulation and UPR (25-27).

Caspase- 4 and CHOP are two key molecules in the three branches of ERS-associated apoptosis: a caspase-4-dependent pathway and/or transcriptional induction of CHOP. CHOP belongs to the C/EBP family of transcription factors. Translocation of CHOP from the cytoplasm to the nucleus regulates the expression of ERS-related genes (28). Overexpression of CHOP promotes cell apoptosis and deficiency or inhibition of CHOP by drugs can protect cells from ERS-induced apoptosis (29). Cascade activation of caspases (such as caspases-3, -8 and -9) play a more important role in cell apoptosis (30). Among 14 known caspases, caspase-12 seems to be involved in signaling pathways specific to ERS-induced apoptosis (14). Cleaved caspase-12 activates caspase-9, followed by activation of caspase-3. Caspase-12knockout mice exhibit resistance to ERS, suggesting that caspase-12 plays a key role in ERS-mediated apoptosis. In humans, caspase-12 protein cannot be produced because the gene is interrupted by a frame shift and a premature stop codon. Caspase-4, another caspase-1 family member, is homologous and functions similarly to mouse caspase-12 (31). In the present study, both cleaved caspase-4 and CHOP were significantly increased in a concentration-dependent manner (Fig. 5). Cleaved caspase-3 was also upregulated in a dose-dependent manner (Fig. 4). Taken together, this study demonstrated that adenosine activated UPR by chaperone GRP78 and UPR triggered CHOP and caspase-4 pathways, finally resulting in caspase- 3 activation and cell apoptosis. However, the precise mechanisms need further investigation.

$\mathrm{NF}-\kappa \mathrm{B}$ is an important mediator of inflammation and carcinogenesis (32). Studies have showed that various agents that induce ERS can activate $\mathrm{NF}-\kappa \mathrm{B}$, and the activated $\mathrm{NF}-\kappa \mathrm{B}$ dimer is rapidly released from the cytoplasm, where it is normally sequestered by the inhibitory unit $\mathrm{I} \kappa \mathrm{B}$, and then is translocated to the nucleus, where it activates transcription 
of downstream genes (33). Active NF- $\kappa \mathrm{B}$ is most commonly composed of the heterodimer DNA binding subunits p50 and p65. The role of NF- $\kappa \mathrm{B}$ in regulating cell death is complex. In some cases it has been demonstrated to promote cell survival and in other cases to promote cell death, which may depend on the cell type and the nature of the toxic stimuli $(34,35)$. In this study, we performed EMSA on nuclear extracts from EC109 cells using a $\kappa$ B sequence from $\kappa$ light chain enhancer in order to observe the effect of different concentrations of adenosine on NF- $\kappa$ B p65 induction. As shown in Fig. 6A, adenosine stimulated DNA binding of $N F-\kappa B$ after $36 \mathrm{~h}$ of incubation at concentrations from 0.5 to $4.0 \mathrm{mmol} / \mathrm{l}$. The effects increased with the adenosine dosage; $4.0 \mathrm{mmol} / 1$ adenosine appeared to more strongly induce $N F-\kappa B$ activation (Fig. 6B). Western blot analysis also revealed that NF- $\kappa \mathrm{B}$ p65 protein expression significantly increased in a dose-dependent manner (Fig. 6C and D). This is consistent with a previous report that demonstrated that high levels of GRP78 expression may promote cellular proliferation by the $\mathrm{NF}-\kappa \mathrm{B}$ pathway (23). In our previous study, we observed that NF- $\kappa \mathrm{B}$ displayed an anti-apoptotic effect on HepG2 cells (36). In this study, we also found that NF- $\mathrm{NB}$ p65 was highly activated and expressed (Fig. 6A and C). We suppose that GRP78-induced activation of UPR both activate the $N F-\kappa B$ pathway and activate ERS-mediated apoptosis pathways by CHOP and cleaved caspase-4. In adenosine-mediated apoptosis, whether the activation of NF- $\kappa \mathrm{B}$ p65 represents a cellular defense mechanism and how $\mathrm{NF}-\kappa \mathrm{B}$ regulates its downstream genes remain to be further investigated.

In summary, the results of this study showed that adenosine inhibited cell proliferation, increased GRP78 and $\mathrm{NF}-\kappa \mathrm{B}$ p65 expression and induced apoptosis by CHOP and caspase- 4 pathways. The ERS pathway may be involved in adenosine-induced EC109 cell apoptosis.

\section{Acknowledgements}

This study was supported by the National Nature Science Foundation of China (no. 30972925).

\section{References}

1. Parkin DM, Bray F, Ferlay J and Pisani P: Global cancer statistics, 2002. CA Cancer J Clin 55: 74-108, 2005.

2. Holmes RS and Vaughan TL: Epidemiology and pathogenesis of esophageal cancer. Semin Radiat Oncol 17: 2-9, 2007.

3. Fredholm BB: Adenosine, an endogenous distress signal, modulates tissue damage and repair. Cell Death Differ 14: 1315-1323, 2007.

4. Galmarini CM, Mackey JR and Dumontet C: Nucleoside analogues and nucleobases in cancer treatment. Lancet Oncol 3: 415-424, 2002

5. Seetulsingh-Goorah SP: Mechanisms of adenosine-induced cytotoxicity and their clinical and physiological implications. Biofactors 27: 213-230, 2006

6. Sun W, Khoo HE and Tan CH: Adenosine induced apoptosis in BHK cells via P1 receptors and equilibrative nucleoside transporters. J Biochem Mol Biol 38: 314-319, 2005.

7. Wu LF, Li GP, Feng JL and Pu ZJ: Molecular mechanisms of adenosine-induced apoptosis in human HepG2 cells. Acta Pharmacol Sin 27: 477-484, 2006.

8. Casas-Tinto S, Zhang Y, Sanchez-Garcia J, Gomez-Velazquez M, Rincon-Limas DE and Fernandez-Funez P: The ER stress factor XBP1s prevents amyloid-beta neurotoxicity. Hum Mol Genet 20: 2144-2160, 2011
9. Cho YM, Jang YS, Jang YM, Chung SM, Kim HS, Lee JH, et al: Induction of unfolded protein response during neuronal induction of rat bone marrow stromal cells and mouse embryonic stem cells. Exp Mol Med 41: 440-452, 2009.

10. Yoshida H, Okada T, Haze K, Yanagi H, Yura T, Negishi M and Mori K: ATF6 activated by proteolysis binds in the presence of NF-Y (CBF) directly to the cis-acting element responsible for the mammalian unfolded protein response. Mol Cell Biol 20: 6755-6767, 2000

11. Dong D, Stapleton C, Luo B, Xiong S, Ye W, Zhang Y, et al: A critical role for GRP78/BiP in the tumor microenvironment for neovascularization during tumor growth and metastasis. Cancer Res 71: 2848-2857, 2011.

12. Misra UK, Payne S and Pizzo SV: Ligation of prostate cancer cell surface GRP78 activates a proproliferative and antiapoptotic feedback loop: a role for secreted prostate-specific antigen. J Biol Chem 286: 1248-1259, 2011.

13. Zinszner H, Kuroda M, Wang X, Batchvarova N, Lightfoot RT, Remotti $\mathrm{H}$, et al: CHOP is implicated in programmed cell death in response to impaired function of the endoplasmic reticulum. Genes Dev 12: 982-995, 1998.

14. Nakagawa T, Zhu H, Morishima N, Li E, Xu J, Yankner BA and Yuan J: Caspase-12 mediates endoplasmic-reticulum-specific apoptosis and cytotoxicity by amyloid-beta. Nature 403: 98-103, 2000.

15. Urano F, Wang X, Bertolotti A, Zhang Y, Chung P, Harding HP and Ron D: Coupling of stress in the ER to activation of JNK protein kinases by transmembrane protein kinase IRE1. Science 287: 664-666, 2000.

16. Wu L, Pu Z, Feng J, Li G, Zheng Z and Shen W: The ubiquitinproteasome pathway and enhanced activity of NF-kappaB in gastric carcinoma. J Surg Oncol 97: 439-444, 2008.

17. Robinson-White AJ, Hsiao HP, Leitner WW, Greene E, Bauer A, Krett NL, et al: Protein kinase A-independent inhibition of proliferation and induction of apoptosis in human thyroid cancer cells by 8-Cl-adenosine. J Clin Endocrinol Metab 93: 1020-1029, 2008.

18. Rapaport E and Fontaine J: Anticancer activities of adenine nucleotides in mice are mediated through expansion of erythrocyte ATP pools. Proc Natl Acad Sci USA 86: 1662-1666, 1989.

19. Yasuda Y, Saito M, Yamamura T, Yaguchi T and Nishizaki T: Extracellular adenosine induces apoptosis in Caco-2 human colonic cancer cells by activating caspase-9/-3 via A(2a) adenosine receptors. J Gastroenterol 44: 56-65, 2009.

20. Hashemi M, Karami-Tehrani F, Ghavami S, Maddika S and Los M: Adenosine and deoxyadenosine induces apoptosis in oestrogen receptor-positive and -negative human breast cancer cells via the intrinsic pathway. Cell Prolif 38: 269-285, 2005.

21. Ghias K, Ma C, Gandhi V, Platanias LC, Krett NL and Rosen ST: 8-Amino-adenosine induces loss of phosphorylation of p38 mitogen-activated protein kinase, extracellular signal-regulated kinase 1/2, and Akt kinase: role in induction of apoptosis in multiple myeloma. Mol Cancer Ther 4: 569-577, 2005.

22. Zhang Y, Liu R, Ni M, Gill P and Lee AS: Cell surface relocalization of the endoplasmic reticulum chaperone and unfolded protein response regulator GRP78/BiP. J Biol Chem 285: $15065-15075,2010$.

23. Misra UK, Deedwania R and Pizzo SV: Activation and crosstalk between Akt, NF-kappaB, and unfolded protein response signaling in 1-LN prostate cancer cells consequent to ligation of cell surface-associated GRP78. J Biol Chem 281: 13694-13707, 2006.

24. Li J and Lee AS: Stress induction of GRP78/BiP and its role in cancer. Curr Mol Med 6: 45-54, 2006.

25. Lee AS: GRP78 induction in cancer: therapeutic and prognostic implications. Cancer Res 67: 3496-3499, 2007.

26. Zhou H, Zhang Y, Fu Y, Chan L and Lee AS: Novel mechanism of anti-apoptotic function of 78-kDa glucose-regulated protein (GRP78): endocrine resistance factor in breast cancer, through release of B-cell lymphoma 2 (BCL-2) from BCL-2-interacting killer (BIK). J Biol Chem 286: 25687-25696, 2011.

27. Rovetta F, Stacchiotti A, Consiglio A, Cadei M, Grigolato PG, Lavazza A, et al: ER signaling regulation drives the switch between autophagy and apoptosis in NRK-52E cells exposed to cisplatin. Exp Cell Res 318: 238-250, 2012.

28. Wang HQ, Du ZX, Zhang HY and Gao DX: Different induction of GRP78 and CHOP as a predictor of sensitivity to proteasome inhibitors in thyroid cancer cells. Endocrinology 148: 3258-3270, 2007. 
29. Li Z, Zhang T, Dai H, Liu G, Wang H, Sun Y, et al: Endoplasmic reticulum stress is involved in myocardial apoptosis of streptozocin-induced diabetic rats. J Endocrinol 196: 565-572, 2008.

30. Mazzoni C and Falcone C. Caspase-dependent apoptosis in yeast. Biochim Biophys Acta 1783: 1320-1327, 2008.

31. Hitomi J, Katayama T, Eguchi Y, Kudo T, Taniguchi M, Koyama Y, et al: Involvement of caspase-4 in endoplasmic reticulum stress-induced apoptosis and Abeta-induced cell death. J Cell Biol 165: 347-356, 2004.

32. Pikarsky E, Porat RM, Stein I, Abramovitch R, Amit S, Kasem $\mathrm{S}$, et al: NF-kappaB functions as a tumour promoter in inflammation-associated cancer. Nature 431: 461-466, 2004.

33. Kucharczak J, Simmons MJ, Fan Y and Gelinas C: To be, or not to be: NF-kappaB is the answer - role of Rel/NF-kappaB in the regulation of apoptosis. Oncogene 22: 8961-8982, 2003.
34. Dolcet X, Llobet D, Encinas M, Pallares J, Cabero A, Schoenenberger JA, et al: Proteasome inhibitors induce death but activate NF-kappaB on endometrial carcinoma cell lines and primary culture explants. J Biol Chem 281: 22118-22130, 2006.

35. Meteoglu I, Erdogdu IH, Meydan N, Erkus M and Barutca S: NF-kappaB expression correlates with apoptosis and angiogenesis in clear cell renal cell carcinoma tissues. J Exp Clin Cancer Res 27: 53, 2008

36. Wu LF, Li GP, Su JD, Pu ZJ, Feng JL, Ye YQ and Wei BL: Involvement of NF-kappaB activation in the apoptosis induced by extracellular adenosine in human hepatocellular carcinoma HepG2 cells. Biochem Cell Biol 88: 705-714, 2010. 